\title{
RED PIGMENT FORMATION BY INTERACTION OF MOLDS \\ PART 3 TAXONOMICAL CHARACTERISTIC OF TRICHODERMA STRAIN L 6
}

\author{
SEIICHI NASUNO and TOSHINOBU ASAI \\ The Institute of Applied Microbiology, University of Tokyo \\ Received for publication, Oct. 5, 1961
}

In the previous papers $(1,2)$ it has been reported that a red pigment formation takes place when some strains of Penicillium verruculosum are grown in contact with some specific fungal strains, although the former, by themselves, are incapable of forming the pigments when grown singularly. A most potent strain causing the pigment formation by interaction with different strains of $P$. verruculosum was found to be a species of Trichoderma. In the study to be reported here this mold was identified as a strain of Trichoderma viride. Some observations dealing with the co-biontic formation of the pigment between this mold and several strains of Penicillium thus far not tested will also be described.

\section{METHODS}

1) Isolation of the mold: The isolation procedure was the same as reported in the previous paper (2). The mold was originally isolated from a mold-spoiled paper label attached to a can of preserved food (3). Some other strains of Trichoderma were also isolated from soil by the authors and several type species were obtained by the courtesy of Dr. Shigeo Abe and Mr. Osamu Terada, Kyowa Fermentation Industry Co..

2) Observation of cultural and morphological characteristics: Koji extract (Balling 10, pH 5.8) agar and glucose-peptone agar containing 4.0\% glucose and $1.0 \%$ Difco-peptone were adjusted to $\mathrm{pH} 6.0$ and used as plate culture media. Spores of the isolated strain, which had been pre-incubated on the koji extract agar slant at $30^{\circ}$ for 10 days, were inoculated at the center of each agar plate in a Petri dish, $86 \mathrm{~mm}$ in inner diameter. The cultures were incubated at $30^{\circ}$ and observations were made of various features of colonies after 1-2 and 5-7 days of incubation. At the 10th to 12th day of culture the morphological characteristics of various organs were studied under a microscope. Color descriptions were made according to RidGway's "Color Standard and Nomenclature."

3) Production of organic acids: Spores of isolated strain L 6 were inoculated into test tubes containing $5 \mathrm{ml}$ of glucose-peptone liquid medium (4.0\% glucose, 1.0\% Difco-peptone, $\mathrm{pH} 6.0$ ) and incubated at $30^{\circ}$ for 48 to 120 hours on a reciprocal shaker. At the end of incubation, culture broth 
was subjected to paper chromatographic analysis for volatile (4) and nonvolatile organic acids.

4) Formation of the red pigments: Red pigment formation caused by interaction of two different fungal strains was investigated by using several strains of the genus Trichoderma, on the one hand, and several strains of $P$. verruculosum and several other representative type species of the genus Penicillium, on the other. Culture media used were koji extract agar and glucose-peptone agar. Spores of the two different test molds were inoculated on one plate at a distance of about $3 \mathrm{~cm}$ and incubated at $30^{\circ}$ for 5 to 7 days.

\section{EXPERIMENTAL RESULTS}

1) Isolation of Trichoderma species: As reported in a previous paper

Table 1. Cultural and microscopic characteristics of Trichoderma viride $\mathrm{L} 6$. (Incubated at $30^{\circ} \mathrm{C}$ on Koji extracts agar)

\begin{tabular}{|c|c|}
\hline \multicolumn{2}{|l|}{ Colony } \\
\hline Rate of growth & Spreading, $65 \mathrm{~mm} / 2$ days \\
\hline Texture & Tufted \\
\hline Surface & $\begin{array}{l}\text { Smooth, sporulation in irregular patch or in } \\
\text { ring form }\end{array}$ \\
\hline Amount of sporulation & Scanty \\
\hline Margin & $2-3 \mathrm{~mm}$, uncolored \\
\hline Color and its change & $\begin{array}{l}\text { White to Pale Olive Buff } \\
\text { Antique Green }\end{array}$ \\
\hline $\begin{array}{l}\text { Color of colony reverse and its } \\
\text { change }\end{array}$ & $\begin{array}{l}\text { Citron Yellow } \\
\text { Uncolored } \\
\text { - Olive Buff }\end{array}$ \\
\hline Odor & Moldy \\
\hline \multicolumn{2}{|l|}{ Microscopic characteristics } \\
\hline \multicolumn{2}{|l|}{ Head } \\
\hline Color & Green \\
\hline Form & Spherical \\
\hline Diameter & $5-10 \mu$ \\
\hline \multicolumn{2}{|l|}{ Conidia } \\
\hline Color & Pale green or yellow \\
\hline Form & Ovate \\
\hline Size & $2.8-4.0 \times 2.0-3.0 \mu$ \\
\hline Markings & Smooth \\
\hline \multicolumn{2}{|l|}{ Phialide } \\
\hline Color & Uncolored \\
\hline Form & Conical or bottle shaped \\
\hline Width & $2.4-3.2 \mu$ \\
\hline Length & $7.2-15.2 \mu$ \\
\hline \multicolumn{2}{|l|}{ Conidiophore } \\
\hline Color & Uncolored \\
\hline Diameter & $2.4-4.0 \mu$ \\
\hline Markings & Smooth, irregulary septate and branched \\
\hline
\end{tabular}


(2), a strain of mold which produced red pigments when, and only when, in contact with $P$. verruculosum L 9, was originally isolated from a moldspoiled paper label attached to a can of preserved food, and it was temporarily named Trichoderma L 6 . Other strains, seemingly also belonging to Trichoderma, were isolated from the same source (L 8), from soil (B, C, $\mathrm{D}, \mathrm{G}$, and $\mathrm{H}$ ) as we'l as from a mold-spoiled carton box used as containers of cans (5).

2) Classification of Trichoderma $L$ 6: Cultural and morphological characteristics of Trichoderma L 6 grown on koji extract agar plate are described in Table 1. Growth on glucose-peptone agar plates was very poor showing almost no mycelial extension, while that on the sucrose-Czapek agar plate was a little better with formation of yellow and green patches of spores. The colony on the koji extract agar plate expanded very rapidly (30 $\mathrm{mm} /$ day) and it showed, at first, a thin, white and tufted texture, some parts of which turned, after 60 to 72 hours of incubation, to antique green or citron yellow in color. To test the possibility that the spores of different colors might be those of different fungal strains, purification procedures with plate cultures were repeated several times; however, they gave rise always to a single strain which produred both yellow and green colors in spore patches. Sporulation occurred in dotted spots, irregular patches or in ring form, and never covered the whole surface of colony.

Conidiophore was smooth in appearance, colorless and sparsely separated. It also branched out 23 times like a tree and the final end consisted of a phialide (Fig. 1).

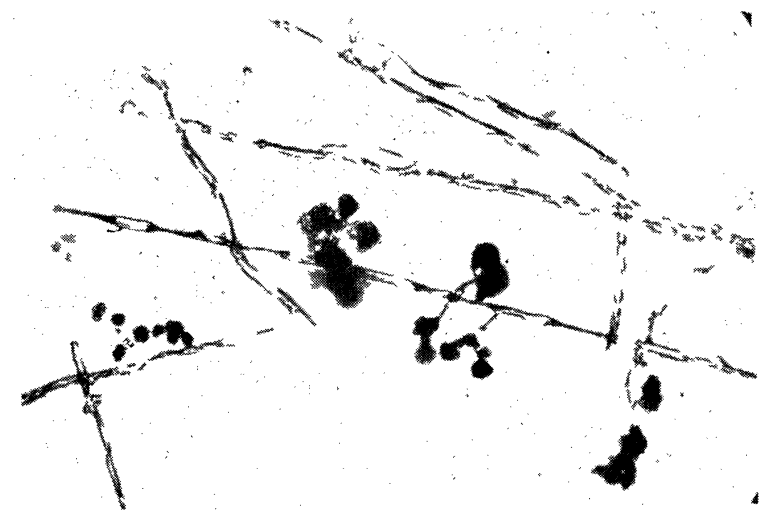

Fig. 1. Conidiophores of Trichoderma viride L 6 .

$(\times 150)$

Conidia were formed at the top of phialide and 30 to 50 conidia were floculated to a slimy ball which was a very flagile. Conidium was a pale green, single cell which was semi-transparent and remarkably light refracting. It was smooth, ovate, and 2.8-4.0 $\mu \times 2.0-3.0 \mu$ in size as shown in Fig. 2 . 


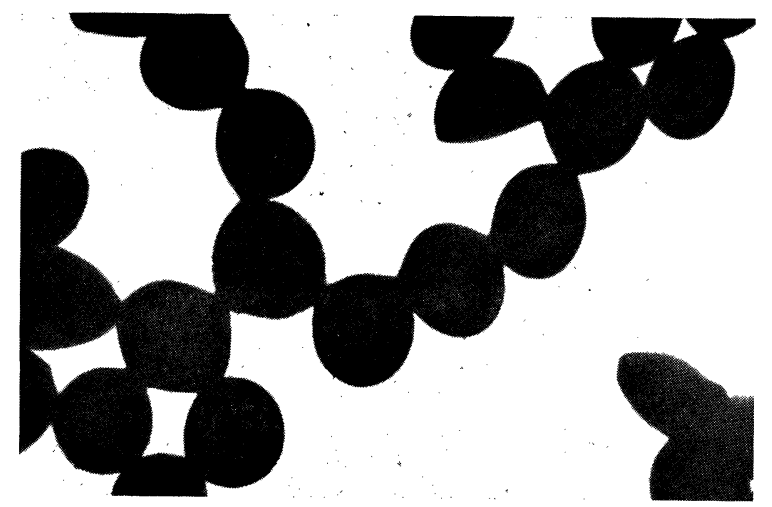

Fig. 2. Electronmicroscopic picture of conidia of Trichoderma viride L 6, showing smooth walls and the globose or subglobose form $(\times 2,500)$

Clamydospores were formed at the middle or end of mycelium in old cultures, and they were colorless and globose or subglobose with a diameter of 8 to $12 \mu$.

Gamogenesis was never found.

Referring the above described characteristics to the key of classification by Gilman (6), this mold strain was supposed to be Trichoderma glaucum Abott. Its properties nearly coincided with descriptions of $T$. viride Pers. ex. Fr. by Bisby $(7)$ or Tsubaki $(8)$ and of $T$. viride isolated by Terada $e t$ al. (9). It also appears to be almost identical with several type species of $T$. viride, T. koningi and T. lignorum obtained from Kyowa Fermentation Industry Co.. The isolated strain differs, however, from all these species in the point that its colony assumes Citron Yellow color. As the molds belonging to the genus Trichoderma, there have been presented 13 species by Saccardo (10), 11 species by Lindau (11) and 4 species by Gilman (6). However, BisBy (7) who scrutinized the properties of all these strains came to the conclusion that the differences among them are so insignificant that they may be better classed as a single species of $T$. viride. Since this proposal of BisBy $(7)$ is now generally adopted, the isolated strain of Trichoderma $\mathrm{L} 6$ is to be named Trichoderma viride $\mathrm{L} 6$.

It should be remarked that a sexual generation of $T$. viride has been reported as Hypocrea rufa or H. gelatinosa (7) (13), which was, however, never observed with our strain.

3) Detection of organic acids: Formation of succinic, malic, oxalic (14) and citric acids (9) by some strains of Trichoderma has been reported, but they were not detected in cultured filtrate of strain L 6 grown in koji extract or glucose-peptone medium.

4) Pigment formation: The isolated strain L 6 never produced any 
Table 2. Formation of yellowish red pigment(s) by interaction among various strains of the genus Trichoderma.

\begin{tabular}{|c|c|c|c|c|c|c|c|c|c|c|}
\hline $\begin{array}{l}\text { Trichoderma } \\
\text { sp. } \\
\text { Trichoderma } \\
\text { sp. }\end{array}$ & 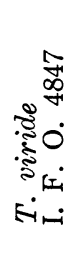 & 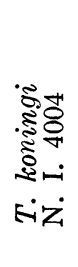 & 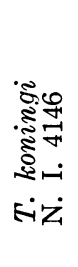 & 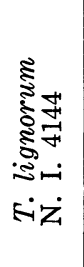 & 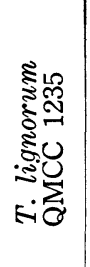 & 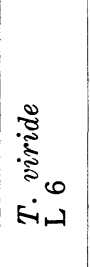 & 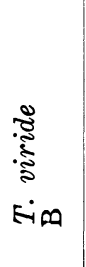 & 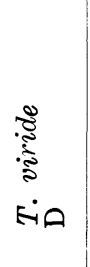 & 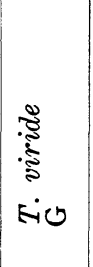 & 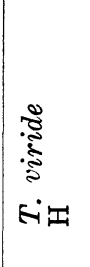 \\
\hline $\begin{array}{l}\text { T. viride } \\
\text { I. F. O. } 4847\end{array}$ & & Y-B & $\mathrm{Y}-\mathrm{Y}$ & $\mathrm{Y}-\mathrm{Y}$ & $\mathrm{Y}-\mathrm{O}$ & $\mathrm{Y}-\mathrm{W}$ & Y-L & $\mathrm{Y}-\mathrm{W}$ & $\mathrm{Y}-\mathrm{W}$ & $\mathrm{Y}-\mathrm{W}$ \\
\hline $\begin{array}{l}\text { T. koningi } \\
\text { N. I. } 4004\end{array}$ & $(-)$ & & B-L & B-L & B-B & B-W & B-L & B-W & B-G & B-Y \\
\hline $\begin{array}{l}\text { T. koningi } \\
\text { N. I. } 4146\end{array}$ & $(-)$ & $(-)$ & & $\mathrm{L}-\mathrm{W}$ & $\mathrm{L}-\mathrm{O}$ & $\mathrm{Y}-\mathrm{W}$ & $\mathrm{Y}-\mathrm{W}$ & $\mathrm{W}-\mathrm{W}$ & $\mathrm{Y}-\mathrm{W}$ & $\mathrm{Y}-\mathrm{W}$ \\
\hline $\begin{array}{l}\text { T. lignorum } \\
\text { N. I. } 4144\end{array}$ & $(-)$ & $(-)$ & $(-)$ & & $\mathrm{W}-\mathrm{W}$ & $\mathrm{O}-\mathrm{Y}$ & O-G & $\mathrm{Y}-\mathrm{W}$ & O-W & $\mathrm{Y}-\mathrm{W}$ \\
\hline $\begin{array}{l}\text { T. lignorum } \\
\text { QMCC } 1235\end{array}$ & $(-)$ & $(-)$ & $(-)$ & $(-)$ & & $\mathrm{O}-\mathrm{Y}$ & O-G & $\mathrm{Y}-\mathrm{W}$ & O-W & $\mathrm{O}-\mathrm{W}$ \\
\hline $\begin{array}{l}\text { T. viride } \\
\mathrm{L} 6\end{array}$ & $(-)$ & $(-)$ & $(-)$ & + & + & & $\mathrm{O}-\mathrm{Y}$ & B-W & $\mathrm{Y}-\mathrm{W}$ & $\mathrm{O}-\mathrm{W}$ \\
\hline $\begin{array}{l}\text { T. viride } \\
\mathrm{B}\end{array}$ & $(-)$ & $(-)$ & $(-)$ & $(-)$ & $(-)$ & $(-)$ & & $\mathrm{L}-\mathrm{W}$ & L-W & W-W \\
\hline $\begin{array}{l}\text { T. viride } \\
\text { D }\end{array}$ & $(-)$ & $(-)$ & $(-)$ & $(-)$ & $(-)$ & $(-)$ & $(-)$ & & $\mathrm{Y}-\mathrm{W}$ & $\mathrm{W}-\mathrm{Y}$ \\
\hline$\underset{\mathrm{G}}{T}$ viride & $(-)$ & $(-)$ & $(-)$ & $(-)$ & $(-)$ & $(-)$ & $(-)$ & $(-)$ & & $\mathrm{W}-\mathrm{W}$ \\
\hline$\underset{\mathrm{H}}{T .}$ viride & $(-)$ & $(-)$ & $(-)$ & $(-)$ & $(-)$ & $(-)$ & $(-)$ & $(-)$ & $(-)$ & \\
\hline
\end{tabular}

Note (1) Above the diagonal line: Color of colony reverse $\mathrm{Y}$ : yellowish green, $\mathrm{O}$ : orange, $\mathrm{W}$ : white, $\mathrm{G}$ : greenish white, L: colorless

(2) Below the line: Formation of yellowish red pigment(s)

pigment on or in various media by itself. Since this strain was identified as $T$. viride, investigations were made to determine whether or not other strains of Trichoderma could produce the red pigments by interaction with the strains of $P$. verruculosum and with some other type species of the genus Penicillium.

(i) Interaction among the strains of Trichoderma: As shown in Table 2 , red pigments were never produced by interaction among the strains of Trichoderma. Only a yellowish orange or orange pigment(s) was produced by interaction of strain L 6 with T. lignorum N. I. 4114 or with T. lignorum 
Table 3. Formation of red pigment(s) in $P$. verruculosum and several species of the genus Trichoderma grown on koji-extracts agar.

\begin{tabular}{|c|c|c|c|c|c|c|}
\hline \multirow{2}{*}{ Strain } & \multicolumn{6}{|c|}{ Plate culture, 5 days, at $30^{\circ} \mathrm{C}$} \\
\hline & Growth* & Sporn. & Color of spore & Reverse & Bounda & \\
\hline T. viride N.I. & $\underset{70<}{\mathrm{mm}}$ & Ht & Meadow Green & D C G & - & $(-)$ \\
\hline " IFO No. 4847 & $70<$ & H & Meadow Green & D C G & - & $(-)$ \\
\hline " IFO No. 5836 & $70<$ & H & $\begin{array}{l}\text { Greenish } \\
\text { Glaucous }\end{array}$ & Green Yellow & - & $(-)$ \\
\hline T. koningi $\quad$ N.I. 4004 & $70<$ & + & $\begin{array}{l}\text { Lemon } \\
\text { Chrome }\end{array}$ & Lemon Chrome & - & $(-)$ \\
\hline " $\quad$ N.I. 4146 & $70<$ & Ht & Meadow Green & D C G & - & $(-)$ \\
\hline T. lignorum N.I. 4144 & $70<$ & 世 & Meadow Green & D C G & - & $(-)$ \\
\hline T. sp. (QMCC-365) & $70<$ & H & Meadow Green & D C G & - & $(-)$ \\
\hline $\begin{array}{l}\text { T. } \text { lignorum } \\
\text { (QMCC 1235) }\end{array}$ & $70<$ & $H$ & Meadow Green & D C G & - & $(-)$ \\
\hline T. viride L 6 & $70<$ & + & $\begin{array}{l}\text { Antique Green } \\
\text { Citron Yellow }\end{array}$ & Olive Buff & Coral Red & 世 \\
\hline $\mathrm{B}$ & 100 & + & $\begin{array}{l}\text { Danube Green } \\
\text { Reed Yellow }\end{array}$ & $\begin{array}{l}\text { Marguerite } \\
\text { Yellow }\end{array}$ & Coral Red & 冊 \\
\hline $\mathrm{C}$ & 90 & H & Danube Green & Stone Green & $\begin{array}{l}\text { Strawberry } \\
\text { Pink }\end{array}$ & $H$ \\
\hline $\mathrm{G}$ & $70<$ & $(-)$ & Uncolored & Olive Buff & Coral Red & H \\
\hline
\end{tabular}

DCG: Deep Chrysolite Green; Growth*: diameter of colony.

QMCC 1235. Considering this and other results to be described later as well as those obtained in a previous paper (2) it may be assumed that the precursor(s) of the red pigments is present on the side of $P$. verruculosum.

(ii) Interaction between several strains of Trichoderma and those of $P$. verruculosum: In Table 3 are presented the results of the red pigment formation by interaction of several strains of Trichoderma with P. verruculosum L 9. Whereas the latter strain, L 9, formed the red pigments by interaction with only 4 strains of the former (Trichoderma), all other strains of $P$. verruculosum, except strain I. A. M. 7081, formed the red pigments by interaction with many species of Trichoderma (Table 4). Since the combinations of the two different molds which produced the red pigments were more than two-thirds of the total combinations, this phenomenon may be regarded as a fairly universal process occurring between $P$. verruculosum and Trichodemra species. The pictures of some examples of pigment formation are given in Fig. 3.

(iii) Interaction between several strains of Trichoderma and some representative species of the genus Penicillium: As shown in Table 5, only $P$. purpurogenum produced the red pigments at the contact areas of its colonies to those of several strains of Trichoderma. However, the color tone and the amount of pigments which were comparable to those found in 
Table 4. Red pigment formation by interaction of several strains of $P$. verruculosum with some species the genus Trichoderma.

\begin{tabular}{|c|c|c|c|c|c|c|c|}
\hline P. verruculosum & $\begin{array}{l}\text { I.A.M. } \\
7058\end{array}$ & $\begin{array}{l}\text { I.A.M. } \\
7064\end{array}$ & $\begin{array}{c}\text { I.A.M.M. } \\
7067\end{array}$ & $\begin{array}{l}\text { I.A.M. } \\
7073\end{array}$ & $\begin{array}{l}\text { I.A.M. } \\
7079\end{array}$ & I.A.M. & L 9 \\
\hline T. viride N.I. & H & H & H & $(-)$ & \pm & $(-)$ & $(-)$ \\
\hline " I.F.O. 4847 & W & H & H & H & $(-)$ & $(-)$ & $(-)$ \\
\hline " I.F.O. 5836 & W & + & H & H & $(-)$ & $(-)$ & $(-)$ \\
\hline T. koningi N.I. 4004 & $(-)$ & + & 册 & + & $(-)$ & $(-)$ & $(-)$ \\
\hline$" \quad$ N.I. 4146 & H & H & WI & H & $(-)$ & $(-)$ & $(-)$ \\
\hline T. lignorum N.I. 4144 & H & H & 册 & 册 & $(-)$ & $(-)$ & $(-)$ \\
\hline T. sp. QMCC 365 & H & H & H & + & $(-)$ & $(-)$ & $(-)$ \\
\hline T. lignorum QMCC 1235 & H & H & m & H & $(-)$ & $(-)$ & $(-)$ \\
\hline T. viride $\quad$ L 6 & $(-)$ & 册 & H & 冊 & $H$ & $(-)$ & 册 \\
\hline $\mathrm{B}$ & $(-)$ & m & H & H & H & $(-)$ & 曲 \\
\hline $\mathrm{C}$ & H & H & m & H & H & $(-)$ & H \\
\hline $\mathrm{D}$ & H & H & m & H & H & $(-)$ & H \\
\hline G & + & H & H & 冊 & + & $(-)$ & W \\
\hline $\mathrm{H}$ & + & 冊 & H & WI & H & $(-)$ & H \\
\hline D3 & H & H & \pm & H & \pm & $(-)$ & $(-)$ \\
\hline D8 & H & H & H & 冊 & $(-)$ & $(-)$ & $(-)$ \\
\hline L8 & H & + & H & m & $(-)$ & $(-)$ & $(-)$ \\
\hline
\end{tabular}

control culture were observed only in the combination of $P$. purpurogenum with T. viride I. F. O. 4847; in the combination of $P$. purpurogenum with other strains of Trichoderma the pigment formation was considerably less and the color tone was fainter. The results obtained here also suggest that the precursor(s) of the red pigments is very likely to be present on the side of $P$. verruculosum and $P$. purpurogenum.

\section{DISCUSSION}

$T$. viride has been well known as a wood-decaying mold and many papers have been published dealing with its formation of cellulase (15-17), amylase, carboxy-methylcellulase, cellobiase, saccharase, lactase and protease (18), antibiotics $(19-21)$, organic acids such as succinic, malic, oxalic and citric acids $(9,14)$, but the process of pigment formation, especially that occurring in its interaction with other molds, has not been reported yet.

Concerning the red pigment formation by interaction of $P$. verruculosum $\mathrm{L} 9$ with $T$. viride $\mathrm{L} 6$, the following results have already been obtained.

(1) When the red-pigmented mycelia appearing in mixed cultures of $P$. verruculosum L 9 and T. viride L 6 were subcultured repeatedly on culture 


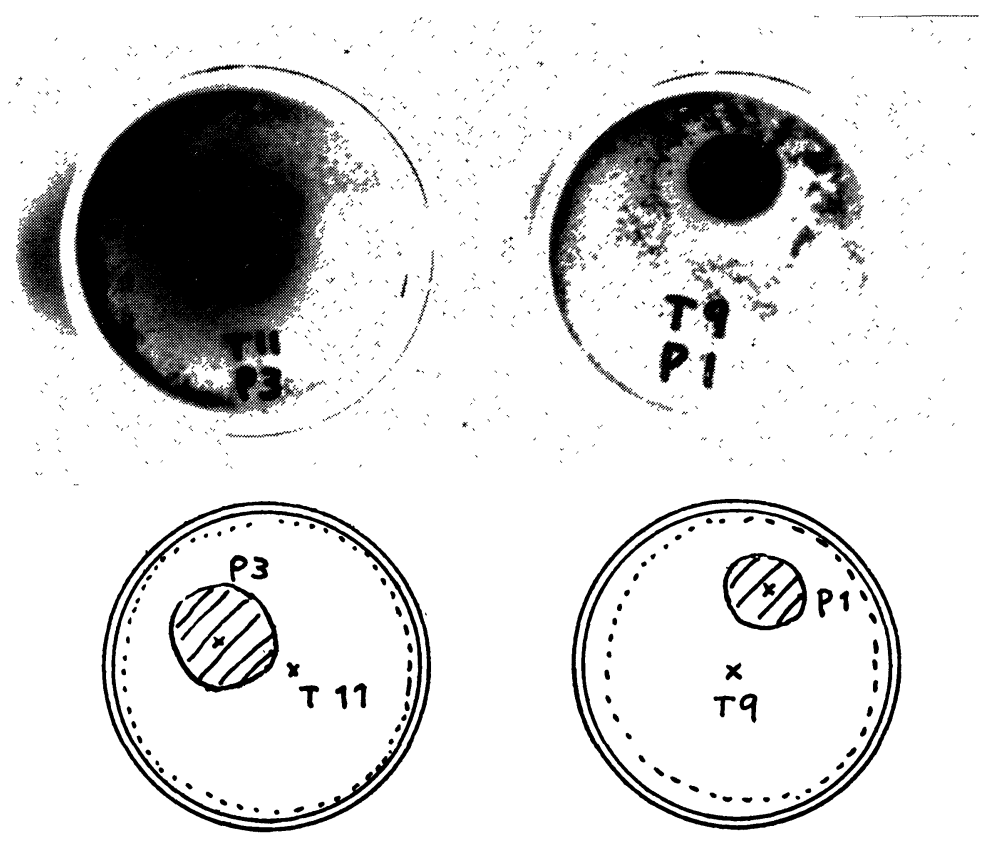

ID Pigmented area covered the whole reverse side of Penicillium colony.

Fig. 3. Red pigment formation by interaction of a strain of P. verru. culosum and that of Trichoderma.

P 3: P. verruculosum I.A.M. 7057

$\mathrm{P}$ 1: P. verruculosum I.A.M. 7058

T11: T. viride $\mathrm{B}$

T 9: T. lignorum QMCC 1235

plates, only former, which grows slower than the latter, was found.

(2) The red pigments were produced by interactions among some strains of $P$. verruculosum, but were never produced by interactions among several strains of Trichoderma examined.

(3) When several strains of $P$. verruculosum were combined with several strains of Trichoderma, it was found that some of the former produced the red pigments in the presence of all of the latter, while none of the latter produced the pigments in combination with all of the former.

Based on these observations it may be assumed that the red pigments may derive from a colorless precursor(s) formed in $P$. verruculosum, which is then converted to the colored material by some action of Trichoderma. The red pigments produced by interaction of $P$. verruculosum with $T$. viride or some other fungi, have been shown in the preceding paper (1) to be composed of several components. Tentatively the author propose the name "verruculosin" for the ensemble of the components forming the red pigment in question. 
Table 5. Red pigment formation by interaction of some species of the genus Trichoderma with some type species of the genus Penicillium.

\begin{tabular}{|c|c|c|c|c|c|c|c|}
\hline Trichoderm & 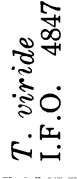 & 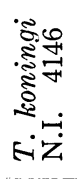 & 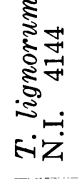 & 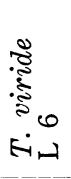 & 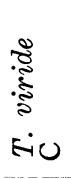 & 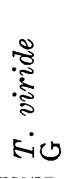 & 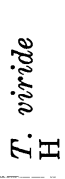 \\
\hline P. thomii & $(-)$ & $(-)$ & $(-)$ & $(-)$ & $(-)$ & $(-)$ & $(-)$ \\
\hline P. vinaceum & $(-)$ & $(-)$ & $(-)$ & $(-)$ & $(-)$ & $(-)$ & $(-)$ \\
\hline P. liliacinum & $(-)$ & $(-)$ & $(-)$ & $(-)$ & $(-)$ & $(-)$ & $(-)$ \\
\hline P. citrinum & $(-)$ & $(-)$ & $(-)$ & $(-)$ & $(-)$ & $(-)$ & $(-)$ \\
\hline P. chrysogenum & $(-)$ & $(-)$ & $(-)$ & $(-)$ & $(-)$ & $(-)$ & $(-)$ \\
\hline P. expansum & $(-)$ & $(-)$ & $(-)$ & $(-)$ & $(-)$ & $(-)$ & $(-)$ \\
\hline P. luteum & $(-)$ & $(-)$ & $(-)$ & $(-)$ & $(-)$ & $(-)$ & $(-)$ \\
\hline$P$. purpurogenum & WI & $(-)$ & \#* & $+^{*}$ & $t^{*}$ & $+^{*}$ & $+*$ \\
\hline P. viniferum & $(-)$ & $(-)$ & $(-)$ & $(-)$ & $(-)$ & $(-)$ & $(-)$ \\
\hline
\end{tabular}

$*=$ Pink.

\section{SUMMARY}

A strain of Trichoderma which produces red pigments by interaction with Penicillium verruculosum was isolated and identified as Trichoderma viride $\mathrm{L} 6$ according to its taxonomical characteristics.

Survey was made of the occurrence of red pigment formation in coupled cultures of various strains belonging to Trichoderma species, $P$. verruculosum as well as some representative species of the genus Penicillium. It was suggested that the red pigment(s) may derive from some colorless precursor formed by $P$. verruculosum, which is later converted to the colored material by the action of $T$. viride or some other molds.

\section{ACKNOWLEDGMENTS}

The authors wish to express their appreciation to Dr. Shigeo Abe and Mr. Osamu Terada, Kyowa Fermentation Industry Co., for their kinds instruction concerning the classification of Trichoderma as well as for their donation of some type cultures of Trichoderma. Thanks are also due to Mr. DaIJI Okuno of this Institute for his cooperation in taking the electronmicroscopic picture of the spores of $T$. viride $\mathrm{L} 6$. 


\section{REFERENCES}

(1) S. Nasuno and T. Asai: J. Gen. Appl. Microbiol. 7, 78 (1961)

(2) S. NASUNo and T. ASAI: Ibid., 8, 9 (1962)

(3) S. Nasuno and T. ASaI: J. Ferm. Soc., 18, 398 (1960)

(4) R. L. ReID and M. LEDERE: Biochem. J., 50, 60 (1951)

(5) S. Nasuno and T. ASAI: J. Paper and Pulp Technol. Soc., 14, 683 (1960)

(6) J. C. Gilman: A Manual of Soil Fungi. p. 212 (1957)

(7) G. R. BisBy: Trans. Brit. Myc. Soc., 23, 149 (1939)

(8) K. Tsubaki: Nagaoya, 4, 12 (1954)

(9) C. Terada, K. Oishi and S. Kinoshita: Nippon Nogei kagaku Kaishi, 34, 166 (1960)

(10) P. A. SACCARDo: Sylloge Fungorum, 4, 59 (1886)

(11) G. LINDAU: Rabenhorst's Kryptogamen-flora, Die Pilze, 8, 110 (1907)

(12) G. Sиiтн: Industrial Mycology, p. 134 (1954)

(13) F. E. Clemen r and C. L. Shear: The Genera of Fungi, p. 58 (1954)

(14) N. Tonoyama: J. Ferm. Technol. (Japan), 32, 300 (1954)

(15) E. T. ReESE: Appl. Microbiol., 4, 39 (1956)

(16) M. MANDEL and E. T. ReESe: J. Bact., 73, 269 (1957)

(17) N. Tonoyama: J. Ferm. Technol. (Japan) 33, 266 (1955); 34, 274 (1956)

(18) N. Tonoyama: Ibid., 35, 311, 356 (1957); 36, 348 (1958)

(19) P. W. BRIAN: Nature, 154, 667 (1944)

(20) P. W. Brian and H. G. Hemming: Ann. Appl. Biol., 32, 214 (1945)

(21) P. W. Brian, H. G. Hemming, P. J. Curtis and J. C. McGowan: Ann. Appl. Biol., 33, 190 (1946) 